\title{
Response of Garlic to Sulphur and Boron Application in Terms of Biochemical Parameters
}

\author{
C.V. Singh ${ }^{1 *}$, Prashant Gupta ${ }^{1}$ and B.S. Kasana ${ }^{2}$ \\ ${ }^{l}$ Department of Horticulture, ${ }^{2}$ Department of Agronomy, College of Agriculture, RVSKVV, \\ Gwalior, 474002, M.P., India \\ *Corresponding author
}

A B S T R A C T

\section{Keywords}

Sulphur, Boron, Garlic TSS, Total chlorophyll content and Volatile oil

Article Info

Accepted:

18 August 2018 Available Online: 10 September 2018
Garlic (Allium sativum L.) is an important bulb crop next to onion. It is one of the most important spice crops in India. Present Experiment was laid out at college of agriculture, Gwalior, during the winter season of 2015-16 and 2016-17. The experimental was laid out in Randomized Block Design with three replications and 16 number of four levels of Sulphur $(0,30,45$ and $60 \mathrm{~kg} / \mathrm{ha})$ and four levels of boron $(0,2,3$ and $4 \mathrm{~kg} / \mathrm{ha})$. Based on two years mean data; it is alluded that by increasing the sulphur and boron levels significantly increased the TSS, Sulphur uptake, boron uptake, total chlorophyll content and volatile oil parameters up to maximum extent. For the sake of recommendation to the garlic growers in Gird region; $B_{3}$ boron level may be recommended with $\mathrm{S}_{3}$ sulphur level.

\section{Introduction}

Garlic (Allium sativum L.) is an important bulb crop next to onion. It is one of the most important spice crops in India. Garlic is a bulbiferous crop belonging to the family Alliaceous. Garlic is native to southern Europe and western Asia (Etoh and Simon, 2002). It is the second most widely cultivated crop in the family after onion (Allium cepa) and contributes $14 \%$ of the world area and $5 \%$ of production. The cloves of garlic bulb are used in flavouring of various vegetarian and nonvegetarian dishes. The significance of this spice is increasing owing to its wide range of medicinal properties. India ranks second in the world in respect of area and production. From India, large amount of dehydrated garlic products is exported to Japan, UK, Italy, Turkey, Germany and France. Garlic is important horticultural crop grown worldwide for culinary and medicinal purpose.

India is a major garlic producing country with 1617.34 thousand tones production from 280.95 thousand hectare area having 5.8t/ha productivity followed by China, which has productivity of $23.53 \mathrm{t} / \mathrm{ha}$. Among the major garlic growing states, Madhya Pradesh ranks first in area (81.17 thousand hectare) and production (424.50 thousand tonnes) with productivity of 5.2t/ha (NHB - 2017).

The yield is very low as compared to the world average yield of $9.67 \mathrm{t}$ ha-1 (FAO, 2002). Successful commercial cultivation of 
this crop depends up on many factors such as climate, soil fertility, irrigation, fertilizer management; spacing, growing season etc. The yield of garlic is quite low because of old and low yielded variety, improper or no use of nutrient and due to continuous depletion of macro and micro nutrients from soil.

Sulphur plays an important role in plant's growth and development. It is involved in the synthesis of amino acids like cystine, cysteine, methionine etc. It is also responsible for characteristic taste and smell of garlic like onion and mustard (Tisdale et al., 1985).

Boron is one of the most widely applied micro-nutrient although it is required in very small quantity. It has different role in plant metabolic activities. Cell division, nitrogen and carbohydrates metabolism and water relation in plants are controlled by boron. Sugar translocation within the plant body is controlled by boron. In deficient condition of boron, growing plants become dead and ultimately the lateral shoots, buds and flowers dies. Chlorosis, thickening and curling of leaves are also observed. Boron also found to increase bulb yield up to $1 \mathrm{~kg} \mathrm{~B} / \mathrm{ha}$ (Francois, 1991).

Most of the researches on nutrition of garlic limit the recommendation for major nutrients like $\mathrm{N}, \mathrm{P}$, and $\mathrm{K}$, but micro-nutrients also play a vital role in deciding the growth and development of plants. Keeping the above facts in view, an experiment was laid out in experimental field of Department of Horticulture, College of Agriculture, Gwalior (M.P.) with the objective to response of garlic to the application of sulphur and boron in terms of biochemical parameters.

\section{Materials and Methods}

Present Experiment was laid out at college of agriculture, Gwalior during the winter season of 2015-16 and 2016-17. Gwalior region receives mean annual rainfall about $751 \mathrm{~mm}$. The monsoon starts in the month of June and often remains active up to September.

The experimental was laid out in Randomized Block Design with three replications and 16 number of four levels of sulphur $(0,30,45 \&$ $60 \mathrm{~kg} / \mathrm{ha})$ and four levels of boron $(0,2,3 \& 4$ $\mathrm{kg} / \mathrm{ha}$ ). Recommended dose of fertilizer; i.e. NPK @ 100:50:50 kg/ha was applied in the in all treatment. Recommended dose of fertilizer i.e., NPK @ 100:50:50 kg/ha was applied in the in all treatment. Basal application of fertilizers, full dose of phosphorus, potassium and $1 / 2$ dose of nitrogen were applied in marked plots respectively. These nutrients supplied by Urea, Di-ammonium phosphate (DAP) and Muriate of Potash (MOP) as per the assigned treatment. Some amount of nitrogen was supplied by DAP and remaining nitrogen was applied through urea as a top dressing in two equal doses at 30 and 45 days after transplanting.

The garlic cultivar used in this study was G282 (Yamuna Safed-3), released from NHRDF Nasik and seed material procured from NHRDF regional center Indore, which is under commercial cultivation in Madhya Pradesh. The sowing time of clove was 10th October, 2015 and 12-10-2016. In the cultural operation, two weeding followed by hoeing were done manually after 30 and 45 days of transplanting. To protect the crop from insects and diseases spray of Imidaclorprid $17 \%$ SL @ 250ml/ha and Carbandazim @ 1 kga.i./ha were done; respectively. Harvesting was done on 03 February 2016 and 07 February 2017 when $70 \%$ of the leaves senesced or fell over gently pulling up individual plants by hand.

In each treatment five plants were randomly selected from each replication for recording biochemical parameters after transplanting and maturity. The observation of total soluble 
solid (TSS) was estimated using hand refractometer and the percent TSS was noted down. The sulphur and boron uptake of matured bulb was determined turbidmetrically using a spectrophotometer method. Leaf material crushed using mortar and pestle added Acetone and $\mathrm{MgCO}_{3}$-kept for 4 hours in freeze at $40 \mathrm{C}$-centrifuge at $500 \mathrm{rpm}$ for 5 minute then measured absorbance on spectrophotometer. Volatile oil content in garlic bulb was determined by using essential oil distillation assembly.

\section{Results and Discussion}

The factors which are directly responsible for ultimate production viz. TSS, Sulphur uptake, Boron uptake, Total chlorophyll content and volatile oil content were augmented almost significantly due to suitable levels of sulphur and boron.

\section{TSS (\%)}

The data pertaining to TSS are presented in Table 1 and 2. This parameter was influenced significantly due to boron and sulphur levels as well as their interaction.

\section{Boron level (B)}

Increasing level of boron exhibited significantly higher TSS value and maximum TSS value of $(30.21 \%)$ was recorded with $\mathrm{B}_{3}$ @ $4 \mathrm{~kg} / \mathrm{ha}$ and was found significantly superior to other treatments under study but was at par with the treatment $B_{2}$ which recorded TSS value of $29.59 \%$. The significantly lowest value for TSS was registered by $\mathrm{B}_{0}(23.93 \%)$.

\section{Sulphur level (S)}

Application of sulphur @ $60 \mathrm{~kg}$ ha $\mathrm{S}_{3}$ recorded significantly maximum value of TSS $(30.51 \%)$ as compared to rest of other treatments.
Whereas, control treatment $\mathrm{S}_{0}$ recorded significantly lowest value $(24.35 \%)$ for TSS.

\section{Interaction $(\mathbf{B} * \mathbf{S})$}

Pooled results reveal that integration of boron @ $4 \mathrm{~kg} / \mathrm{ha}$ and sulphur @ $60 \mathrm{~kg} / \mathrm{ha}\left(\mathrm{B}_{3} \mathrm{~S}_{3}\right.$ treatment) recorded significantly maximum TSS value of $32.80 \%$ as compared to all other treatments. However control treatment $\mathrm{B}_{0} \mathrm{~S}_{0}$ recorded significantly lower value of $(22.71 \%)$ for TSS.

\section{Sulphur uptake $(\%)$}

The data pertaining to sulphur uptake are presented in Table 1 and 2.

This parameter was influenced significantly due to boron and sulphur levels however interaction effect was not found significant.

\section{Boron level (B)}

Increasing level of boron exhibited significantly higher sulphur uptake and maximum sulphur uptake of $(1.71 \%)$ was recorded with $\mathrm{B}_{3} @ 4 \mathrm{~kg} / \mathrm{ha}$ and was found significantly superior to other treatments under study. The significantly lowest value for sulphur uptake was registered by $\mathrm{B}_{0}(1.26 \%)$.

\section{Sulphur level (S)}

Application of sulphur @ $60 \mathrm{~kg}$ ha $\mathrm{S}_{3}$ recorded significantly maximum value of sulphur uptake $(1.69 \%)$ as compared to rest of other treatments. Whereas, control treatment $\mathrm{S}_{0}$ recorded significantly lowest value (1.16\%) for sulphur uptake.

\section{Boron uptake (\%)}

The data pertaining to boron uptake are presented in Table 1, 2 and Figure 1. This parameter was influenced significantly due to 
boron and sulphur levels however interaction effect was found non-significant.

\section{Boron level (B)}

Increasing level of boron exhibited significantly higher boron uptake and maximum boron uptake of (1.56\%) was recorded with $\mathrm{B}_{3} @ 4 \mathrm{~kg} / \mathrm{ha}$ and was found significantly superior to other treatments under study.

The significantly lowest value for boron uptake was registered by $\mathrm{B}_{0}(1.09 \%)$.

\section{Sulphur level (S)}

Application of sulphur @ $60 \mathrm{~kg}$ ha $\mathrm{S}_{3}$ recorded significantly maximum value of boron uptake $(1.52 \%)$ as compared to rest of other treatments.

Whereas, control treatment $\mathrm{S}_{0}$ recorded significantly lowest value $(1.01 \%)$ for boron uptake.

\section{Total chlorophyll content (mg/100 fw)}

The data pertaining to total chlorophyll content are presented in Table 1, 2 and Figure 1. This parameter was influenced significantly due to boron and sulphur levels as well as their interaction.

\section{Boron level (B)}

Total chlorophyll content was observed significantly increasing with increasing levels of boron. Application of boron $\mathrm{B}_{3} @ 4 \mathrm{~kg} / \mathrm{ha}$ recorded significantly higher value (24.66 $\mathrm{mg} / 100 \mathrm{fw}$ ) for chlorophyll content during both the seasons i.e. $2015-16$ and 2016-17 as compared to rest of the treatments. The minimum chlorophyll content was noticed under $\mathrm{B}_{0}$ level $(21.95 \mathrm{mg} / 100 \mathrm{fw})$ at all the stages.

\section{Sulphur level (S)}

Chlorophyll content was observed significantly increasing with increasing levels of sulphur. Application of sulphur $\mathrm{S}_{3} @ 60$ $\mathrm{kg} / \mathrm{ha}$ recorded significantly maximum value for chlorophyll content $(24.85 \mathrm{mg} / 100 \mathrm{fw})$ during both the seasons i.e. 2015-16 and 201617 as compared to rest of the treatments except $S_{2}(23.74 \mathrm{mg} / 100 \mathrm{fw})$ which was at par with $\mathrm{S}_{3}$. The minimum chlorophyll content was noticed under $B_{0}$ level $(22.08 \mathrm{mg} / 100 \mathrm{fw})$ at all the stages.

\section{Interaction $(\mathbf{B} * \mathbf{S})$}

Pooled analysis reflected that chlorophyll content was observed significantly higher (26.56 mg/100 fw) with $\mathrm{B}_{3} \mathrm{~S}_{3}\left(\mathrm{~B}_{3} @ 4 \mathrm{~kg} / \mathrm{ha}\right.$ and $S_{3} @ 4 \mathrm{~kg} / \mathrm{ha}$ ) treatment as compared to all other treatments.

While minimum value (20.75 mg/100 fw) was noticed under treatment combination $\mathrm{B}_{0} \mathrm{~S}_{0}$ at all stage of plant growth.

\section{Volatile oil (\%)}

The data pertaining to volatile oil percent are presented in Table 3 and Figure 2. This parameter was influenced significantly due to boron and sulphur levels however, the interaction effect was not observed statistically significant.

\section{Boron level (B)}

Volatile oil was observed significantly increasing with increasing levels of boron. Application of boron $\mathrm{B}_{3} @ 4 \mathrm{~kg} / \mathrm{ha}$ recorded significantly higher value $(0.54 \%)$ for volatile oil content during both the seasons i.e. 201516 and 2016-17 as compared to rest of the treatments. The minimum volatile oil content was noticed under $\mathrm{B}_{0}$ level $(0.48 \%)$ at all the stages. 
Table.1 Response of Garlic to Sulphur and Boron in terms of biochemical parameters

\begin{tabular}{|c|c|c|c|c|c|c|c|c|c|c|c|c|}
\hline \multirow[t]{2}{*}{ Treatment } & \multicolumn{3}{|c|}{ TSS (\%) } & \multicolumn{3}{|c|}{ S uptake (\%) } & \multicolumn{3}{|c|}{ B uptake (\%) } & \multicolumn{3}{|c|}{$\begin{array}{l}\text { Total chlorophyll content } \\
(\mathrm{mg} / 100 \mathrm{fw})\end{array}$} \\
\hline & 2015-16 & 2016-17 & Pooled & 2015-16 & 2016-17 & Pooled & 2015-16 & 2016-17 & Pooled & 2015-16 & 2016-17 & Pooled \\
\hline B0 & 23.90 & 23.96 & 23.93 & 1.25 & 1.26 & 1.26 & 1.08 & 1.10 & 1.09 & 21.93 & 21.97 & 21.95 \\
\hline B1 & 26.56 & 26.62 & 26.59 & 1.41 & 1.42 & 1.42 & 1.19 & 1.21 & 1.20 & 22.86 & 22.90 & 22.88 \\
\hline B2 & 29.56 & 29.62 & 29.59 & 1.58 & 1.59 & 1.58 & 1.44 & 1.46 & 1.45 & 23.94 & 23.98 & 23.96 \\
\hline B3 & 30.18 & 30.24 & 30.21 & 1.70 & 1.71 & 1.71 & 1.55 & 1.57 & 1.56 & 24.64 & 24.68 & 24.66 \\
\hline SEm & 0.47 & 0.47 & 0.33 & 0.08 & 0.08 & 0.06 & 0.06 & 0.06 & 0.04 & 0.28 & 0.28 & 0.20 \\
\hline $\mathrm{CD}$ & 1.34 & 1.34 & 0.93 & 0.23 & 0.23 & 0.16 & 0.17 & 0.17 & 0.12 & 0.81 & 0.81 & 0.56 \\
\hline So & 24.32 & 24.38 & 24.35 & 1.16 & 1.17 & 1.16 & 1.00 & 1.02 & 1.01 & 22.06 & 22.10 & 22.08 \\
\hline S1 & 26.75 & 26.81 & 26.78 & 1.47 & 1.48 & 1.47 & 1.29 & 1.31 & 1.30 & 22.76 & 22.80 & 22.78 \\
\hline S2 & 28.65 & 28.71 & 28.68 & 1.64 & 1.65 & 1.64 & 1.46 & 1.48 & 1.47 & 23.72 & 23.76 & 23.74 \\
\hline S3 & 30.48 & 30.54 & 30.51 & 1.68 & 1.69 & 1.69 & 1.51 & 1.52 & 1.52 & 24.83 & 24.87 & 24.85 \\
\hline SEm & 0.47 & 0.47 & 0.33 & 0.08 & 0.08 & 0.06 & 0.06 & 0.06 & 0.04 & 0.28 & 0.28 & 0.20 \\
\hline $\mathrm{CD}$ & 1.34 & 1.34 & 0.93 & 0.23 & 0.23 & 0.16 & 0.17 & 0.17 & 0.12 & 0.81 & 0.81 & 0.56 \\
\hline B*S & & & & & & & & & & & & \\
\hline SEm & 0.93 & 0.93 & 0.66 & 0.55 & 0.55 & 0.11 & 0.45 & 0.45 & 0.12 & 0.56 & 0.56 & 0.40 \\
\hline $\mathrm{CD}$ & NS & NS & 1.86 & NS & NS & NS & NS & NS & NS & NS & NS & 1.12 \\
\hline
\end{tabular}


Table.2 Response of garlic to interaction $(\mathrm{S} * \mathrm{~B})$ in terms of biochemical parameters (Pooled)

\begin{tabular}{|c|c|c|c|c|c|c|c|c|}
\hline \multirow[t]{3}{*}{ Treatment } & \multicolumn{8}{|c|}{ Biochemical parameters } \\
\hline & \multicolumn{4}{|c|}{ TSS $(\%)$} & \multicolumn{4}{|c|}{ Total chlorophyll content (mg/100 fw) } \\
\hline & B0 & B1 & B2 & B3 & B0 & B1 & B2 & B3 \\
\hline So & 22.71 & 23.37 & 25.14 & 26.17 & 20.75 & 21.50 & 22.62 & 23.44 \\
\hline $\mathbf{S 2}$ & 23.83 & 27.48 & 31.54 & 31.88 & 22.35 & 23.51 & 24.27 & 24.81 \\
\hline S3 & 26.05 & 31.14 & 32.07 & 32.80 & 23.43 & 24.01 & 25.39 & 26.56 \\
\hline
\end{tabular}

Table.3 Response of garlic to sulphur and boron application in terms of Total Volatile oil \% in Bulb of garlic

\begin{tabular}{|c|}
\hline Treatment \\
\hline B0 \\
\hline B1 \\
\hline B2 \\
\hline B3 \\
\hline SEm \\
\hline CD \\
\hline S0 \\
\hline S1 \\
\hline S2 \\
\hline S3 \\
\hline SEm \\
\hline CD \\
\hline B*S \\
\hline SEm \\
\hline CD \\
\hline
\end{tabular}

\begin{tabular}{|c|c|c|}
\hline & \multicolumn{2}{|c|}{ Total volatile oil \% in Bulb } \\
\hline $\mathbf{2 0 1 5 - 1 6}$ & $\mathbf{2 0 1 6 - 1 7}$ & Pooled \\
\hline 0.47 & 0.48 & 0.48 \\
\hline 0.50 & 0.51 & 0.50 \\
\hline $0 . .51$ & 0.52 & 0.51 \\
\hline 0.54 & 0.55 & 0.54 \\
\hline 0.01 & 0.01 & 0.00 \\
\hline 0.02 & 0.02 & 0.01 \\
\hline 0.47 & 0.47 & 0.47 \\
\hline 0.48 & 0.50 & 0.49 \\
\hline 0.51 & 0.53 & 0.52 \\
\hline 0.55 & 0.57 & 0.56 \\
\hline 0.01 & 0.01 & 0.00 \\
\hline 0.02 & 0.02 & 0.01 \\
\hline
\end{tabular}


Fig.1 Response of garlic to sulphur and boron application in terms of biochemical parameters (TSS\%, S uptake\%, B uptake \% and total chlorophyll content $\mathrm{mg} / 100 \mathrm{fw}$ ) of garlic

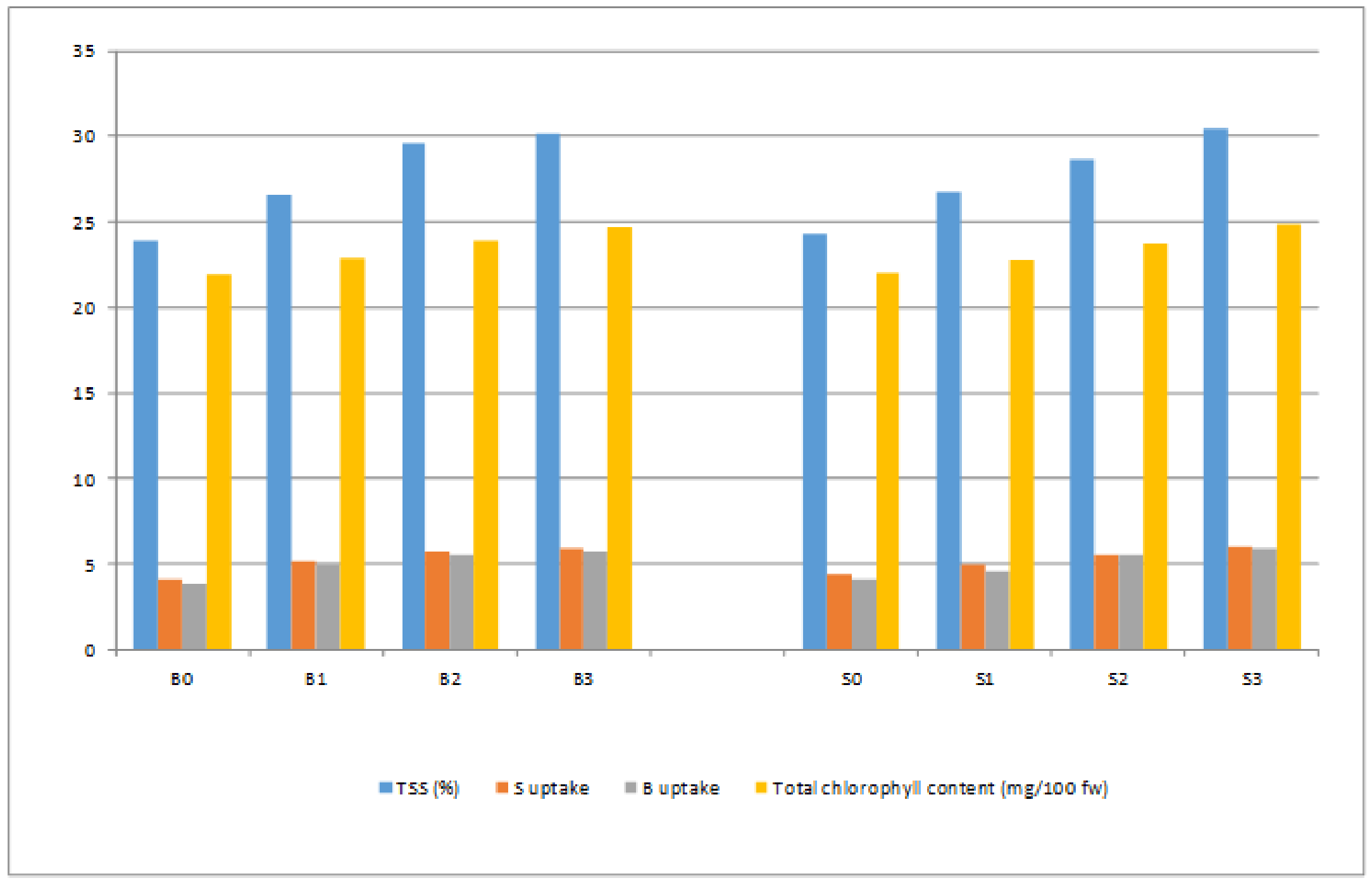


Fig.2 Response of garlic to sulphur and boron application in terms of total volatile oil \% in bulb of garlic

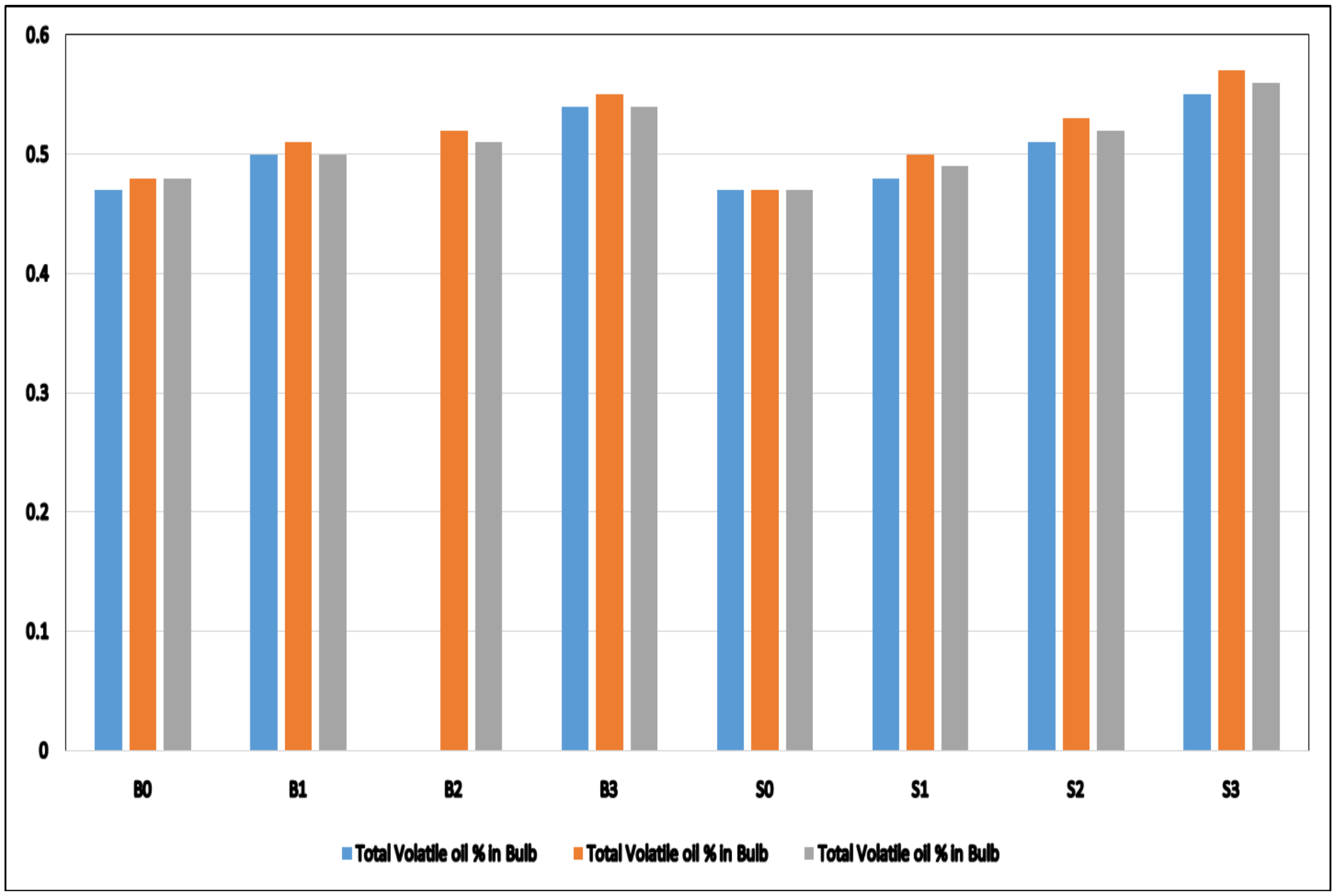




\section{Sulphur level (S)}

Volatile oil content was observed significantly increasing with increasing levels of sulphur. Application of sulphur $S_{3} @ 60$ $\mathrm{kg} / \mathrm{ha}$ recorded significantly maximum value for volatile oil content $(0.56 \%)$ during both the seasons i.e. 2015-16 and 2016-17 as compared to rest of the treatments. The minimum volatile oil content was noticed under $\mathrm{S}_{0}$ level $(0.47 \%)$ at all the stages.

\section{Interaction $(\mathbf{B} * \mathbf{S})$}

The maximum value of Volatile oil percent was noticed under interaction of $B_{3}$ with $S_{3}$; however, there was not any significant difference was recorded due to the interaction of sulphur and boron.

Boron applications at higher levels (4 kg/ha) significantly improved T.S.S content, sulphur uptake, boron uptake, total chlorophyll content and volatile oil content of garlic bulbs as compared to lower levels of boron. This might have been caused by increased production of carbohydrates during photosynthesis due to increased uptake of nutrients by crop and photosynthates might have been translocated from leaves to bulb. Similar findings have been reported by Sindhu and Tiwari (1991), Shrivastav et al., (2005), Manna et al., (2014) and Manna and Maity (2016).

T.S.S content, sulphur uptake, boron uptake, total chlorophyll content and volatile oil content of garlic bulbs was observed significantly higher $(30.21 \%)$ by sulphur applications $\mathrm{S}_{3} @ 60 \mathrm{~kg} / \mathrm{ha}$ as compared to lower levels of sulphur $\left(\mathrm{S}_{2}, \mathrm{~S}_{1}\right.$ and $S_{0}$ ).Whereas, control treatment $S_{0}$ recorded significantly lowest value for these parameters. This might have been possible due to increased synthesis of photosynthates including sugars whose production increase with increase in $\mathrm{S}$ levels as reported by Channagoudra (2004), Dabhi et al., (2004), Abdel-Mouty et al., (2011) in brinjal, Najar et al., in soyabean (2011), Elsayed et al., (2012) in garlic, Verma and Singh in onion (2012) and Tripathy et al., (2013) in onion.

Integration of boron $(4 \mathrm{~kg} / \mathrm{ha})$ and sulphur $(60$ $\mathrm{kg} / \mathrm{ha}$ ) has proved superior as compared to their sole effects. Pooled analysis showed that treatment B3S3 (4 kg B/ha $+60 \mathrm{~kg} \mathrm{~S} / \mathrm{ha})$ recorded significantly maximum value of all the biochemical parameters as compared with other lower interaction levels of sulphur and potassium. The higher uptakes of nutrients with addition of boron might be attributed to increased vigour of crop growth with enhanced nutrient utilization and translocation into the plant resulting in the enhancement of bulb yield.Uptake of sufficient nutrient by the garlic crop is important to improve growth, yield and marketable proportions as well as quality of the crop (Nai-hua et al., 1998). Improved management of nitrogen, phosphorus, potassium and other inputs in the soil could improve yields and quality of vegetables and other crops (Nai-hua et al., 1998). Gupta and Ganeshe (2000) revealed that zinc sulphate $(25 \mathrm{~kg} / \mathrm{ha})+$ borax $(10 \mathrm{~kg} / \mathrm{ha})$ promoted yield marginally by $45.8 \mathrm{~kg} / \mathrm{ha}$ in garlic over the control (recommended dose of N, P and K. Application of boron at $0.1 \%+$ sodiummolybdate at $0.05 \%(\mathrm{w} / \mathrm{v})$ recorded the highest healthy bulb yield and reduced premature field-sprouting of Cloves (Selvaraj et al., 2002). Srivastava et al., (2005) reported that boric acid at $0.1 \%$ and zinc sulfate at $0.4 \%$ resulted in maximum bulb yield and total soluble solids. Jermsiri et al., (1995) reported that applying borax to garlic increased the yield by $24-40 \%$.

Based on two years mean data; it is concluded that amongst the sulphur and boron levels raised all the above biochemical parameters 
(TSS, B and S Uptake, Total chlorophyll content and Volatile oil content)up to maximum extent. For the sake of recommendation to the garlic growers in Gird region; $B_{3}$ (@ 4 kh/ha.) boron level may be recommended with $\mathrm{S}_{3}(60 \mathrm{~kg} / \mathrm{ha}$.) sulphur level for maximum yield of biochemical parameters in garlic (cv. G-282). Present study is very useful to find out the new ways in micro nutrient requirement of garlic crop. Study will used as ready reference for further research in the field of garlic nutrition, quality aspects and biochemical parameters

\section{Acknowledgement}

Authors are thankful to Rajmata Vijayaraje Scindia Krishi Vishwa Vidyalaya, Raja Pancham Singh Marg, Gwalior, 560065, M. P. for providing technical advice and guidance for conducting the research effectively.

Author is highly grateful to chairman and guide, Dr P.K. Gupta, Scientist, Horticulture, Department of Vegetable Science, Dr. Rajesh Lekhi, Professor and Head, Department of Horticulture, Mr. B.S. Kasana, S.M.S. Agronomy, College of Agriculture, Gwalior (M.P.),for his guidance in successfully completing of this research work.

\section{Abbreviations}

\section{a.i.: Active ingredient}

B: Boron

fw: Fresh weight

Ha: Hectare

$\mathrm{K}$ : Potash

Kg: Kilogram

mg: Milligram

N: Nitrogen

P: Phosphorus

S: Sulphur

TSS: Total Soluble Solid

\section{Author Contributions}

C.V. Singh: Carried out research work, data collection and paper writing

Prashant Gupta: Chairman of research committee, assisted in carrying research work.

B.S. Kasana: Technical guidance during research work and paper writing.

\section{References}

Abdel-Mouty, M., Mahmoud Asmaa, R.M., EL-Desuki and Rizk, F.A. 2011. Yield and fruit quality of eggplant as affected by organic and mineral fertilizers application. Research Journal of Agriculture and Biological Sciences 7(2): 196-202.

Channagoudra, R.F. 2004. Response of onion (Allium cepa L.) to irrigation schedule and sulphur levels in northern transitional zone of Karnataka, M.Sc. (Agri.) Thesis, University of Agricultural Sciences, Dharwad.

Dabhi, N.M., Patel, M.V. and Patil, V.R. 2004. Effect of sources and levels of sulphur on yield and chemical composition of onion in loamy soil. National Seminar on Development in Soil Science. $69^{\text {th }}$ AnnualConvention, Hyderabad, October 27-30, pp. 124.

El Sayed, H.A. and El Morsey, A.H.A. 2012. Response of productivity andstorability of garlic (Allium sativum L.) to some potassium levels and foliar spray with mepiquatcholoride (pix). International ResearchJournal of Agricultural Sciences and Soil Science. 2(7): 298305.

Etoh T. and Simon P.W. (2002) Diversity, fertility and seed production of garlic, p. 101-118. In; H.D. Rabinowitch and L. Currah (eds.). Advances in Allium science. CAB intl., New York. 
FAO (2002). The market for non-traditional agricultural exports. FAO commodities and trade technical paper 3.

Francois L.E. (1991) Hort Science, 26(3), 547-549.

Gupta NK, Ganeshe RK. Response of borax and zinc sulphate on growth and yield of garlic (Allium sativum L.). Adv. Pl. Sci. 2000; 13:237-239.

Indian Horticulture Database (2017). Ministry of Agriculture, Government of India, www.nhb.gov.in

Jermsiri J, Watanabe H, Addhajarusith S, Tantivoravith J. Effects of boron on growth of garlic. Thai Agril. Sci. 1995; 28(1-3):25-38. (In Thai with English abstract).

Manna D and Maity TK. (2016). Growth, yield and bulb quality of onion (Allium cepa L.) in response to foliar application of boron and zinc, Journal of Plant Nutrition, 39(3): 438-441.

Manna D, Maity TK and Ghosal A. (2014). Influence of foliar application of boron and zincon growth, yield and bulb quality of onion (Allium cepa L.). Journal of Crop and Weed 10 (1): 5355.

Nai-hua Y, Dingguo Z, Wang J. Phosphorus and Potassium Nutrient Management for Vegetable Soils in Shanghai and Guangdong. In: Donald L. Armstrong (Ed.), Better Crops International, 1998; 12(1):1.

Najar, G.R., Singh, S.R., Akhtar, F. and Hakeem, S.A. 2011. Influence of sulphurlevel on yield, uptake and quality of soybean under temperate conditions of Kashmir valley. Indian Journal of Agricultural Sciences, 81: 340-343.

Selvaraj NS, Natarajan VM, Selvarajan Mathews S, Pabitha A. Effect of foliar application of micronutrients on the growth and yield of garlic. S. Ind. Hort., 2002; 50:159-168.

Sindhu SS and Tiwari RS. (1993). Effect of micronutrients on yield and quality of onion (Allium cepaL.) cv. Pusa Red. Progressive Hort., 25(3-4):176-180.

Srivastava, R.; Agarwal, A.; Tiwari, R.S. and Kumar, S. (2005). Effect of micronutrients, zinc and boron on yield, quality and storability of garlic (Alliurn sativum). Indian J. Agril. Sciences, 75 (3): 157-159.

Tisdale S.L., Nelson W.L. and Beaton J.D. (1985) Soil Fertility and Fertilizers, 4th edition. Macmillan Publication Company, New York.

Tripathy, P., Sahoo, B.B., Priyadarshini, A., Das, S.K. and Dash, D.K. 2013.Effect of sources and levels of sulphur on growth, yield and bulb qualityin onion (Allium cepa L.). International Journal of Bio-resource and Stress Management, 4(4): 641-644.

Verma, D. and Singh, H. 2012. Response of varying levels of potassium and sulphur on yield and uptake of nutrients by onion. Annals of Plant and Soil Research, 14(2): 143-146.

\section{How to cite this article:}

Singh, C.V., Prashant Gupta and Kasana, B.S. 2018. Response of Garlic to Sulphur and Boron Application in Terms of Biochemical Parameters. Int.J.Curr.Microbiol.App.Sci. 7(09): 26772687. doi: https://doi.org/10.20546/ijcmas.2018.709.333 